\title{
MORE MONEY MORE PROBLEMS: ANALYZING THE EFFICACY OF GOVERNMENTAL INTERVENTION IN INCENTIVIZING SOCIAL ENTREPRENEURSHIP
}

\author{
Prithvi Raj Agrawal \\ Delhi Public International School \\ DOI: 10.46609/IJSSER.2020.v05i09.023 URL: https://doi.org/10.46609/IJSSER.2020.v05i09.023
}

\begin{abstract}
Social entrepreneurship has grown rapidly as a movement in developing countries, and especially India. Social entrepreneurs seek to solve issues caused by market failures in the private and public sector, by creating a nexus between profitability as well as creating socially sustainable solutions, often targeted towards the poor and marginalized communities. Given the unique role played by social enterprises in the economy, a relevant debate is whether government intervention to incentivize the same is desirable when the sector is geared to target issues which the government has proven incapable of doing. However, in several countries including India, social enterprises would not have achieved a large scale if not for institutional support. This paper will analyze this contemporary debate and shed light on the various advantages and disadvantages of government intervention in the sector, as well as pose policy recommendations for the better integration of a hybridized partnership between governments and social entrepreneurs.
\end{abstract}

Keywords: Money, social entrepreneurs, government, market, communities.

\section{Introduction}

Especially in the context of developing countries like India with a high level of the population living in poverty, social entrepreneurship has become an effective model for empowerment. India has the world's second largest labour force of 516.3 million people and although hourly wage rates in India have more than doubled over the past decade, the latest World Bank report states that approximately 350 million people in India currently live below the poverty line (Mante, 2019). Given these statistics, there is a clear and urgent need for job creation and increasing skilled employment. With an estimated population of 1.2 billion people, this means that every third Indian is bereft of even basic necessities like nutrition, education and health care and many are still blighted by unemployment and illiteracy (Mante, 2019). Social entrepreneurs 


\section{International Journal of Social Science and Economic Research}

ISSN: 2455-8834

Volume:05, Issue:09 "September 2020"

can play a key role in alleviating these issues by putting those less fortunate on a path towards a worthwhile life. Rather than leaving societal needs to the government or business sectors, they can solve the problem by changing the system (Mante, 2019).

However, there have been debates regarding the intensity of government intervention that is ideal for spurring development in the social entrepreneurship sector, especially the role of the government in incentivizing the development of social entrepreneurship models to begin with. Given that the primary pursuit of the social entrepreneurship model is different from the traditional NGO business model, government intervention remains a relevant consideration. Social Entrepreneurship is the process of bringing about social change on a major and more effective scale than a traditional Non-Governmental Organisation (NGO). They differ from NGOs in that they aim to make broad-based, long-term changes, instead of small-scale and timelimited changes (Mante, 2019). In order to protect the financial sustainability of these businesses, it is crucial to understand both the advantages and disadvantages of government intervention.

This paper will analyze the efficacy of such governmental intervention, and highlight the key arguments in favour and against the same. The paper will analyze government schemes in the context of developing countries from a critical theoretical perspective, and conclude with policy recommendations on suitable models to best optimize the incentivizing of social entrepreneurship models.

\section{Background}

Social innovation and entrepreneurship has grown rapidly as a movement in the past few decades. This rapid development can be especially seen in the case of India, in the developing country context. In the past decade, India has witnessed considerable growth in its social enterprise activity. The number and quality of innovative ideas and business plans has improved due to growing awareness, support, and quality training and workshops available for social entrepreneurs and social enterprise leaders (British Council, 2016). The social enterprise ecosystem has evolved with support organisations providing direct, indirect, financial, and advisory assistance to social enterprises (British Council, 2016). Cooperative and communityowned business models like Amul and Fabindia have existed in India since the 1950s, and the global social entrepreneur support organisation, Ashoka, introduced the term 'social entrepreneur' in 1981 (British Council, 2016). The Indian social enterprise ecosystem is the among the most developed among the Global South, with a wide and growing range of domestic and international investors and support organisations (British Council, 2016).

The social entrepreneurship model has been especially important in the context of rural development and employment increase among the poorest sections of rural society. For example, 


\section{International Journal of Social Science and Economic Research}

ISSN: $2455-8834$

Volume:05, Issue:09 "September 2020"

the model has been instrumental in empowering rural women in India. Social enterprises offer a way for more women in rural areas to contribute to country's growth and provide innovative, sustainable solutions to its long entrenched social problems (Khanna, 2015). Indian women social entrepreneurs are making great strides in addressing social problems and bringing about transformational change (Khanna, 2015). The social enterprise sector is ripe for realizing the multiplier effects of women's leadership in rural areas, as women are more likely to hire other women, to focus on women beneficiaries, and to pass on their gains to female family members (Salovaara and Wade, 2018). This is especially true in India, where nearly 25 percent of social enterprises are led by women (Salovaara and Wade, 2018).

Researchers in the field have long debated the issue of whether government schemes and incentivization is effective, or whether it should be limited in the context of social entrepreneurship. Government leaders and social entrepreneurs share an interest in identifying efficient, effective, and sustainable ways to solve difficult social problems (Wolk, 2007). Despite this common goal, however, little has been published by scholars and researchers to date on the relationship between the two (Wolk, 2007). Much social entrepreneurship has occurred in developing countries with national governments with low levels of state capacity to address social problems (Shockley and Frank, 2011). However, there is evidence to suggest that the social change resulting from social entrepreneurship could not have become 'large-scale' without the enabling institutions, resources, and policies of government, even ones with reputations for inefficiency or corruption (Shockley and Frank, 2011).

Social entrepreneurship also draws from characteristics of all three major sectors of the economy - private, nonprofit, and governmental. In doing so, the sector addresses market failures that have resulted from the operation of the free market (Wolk, 2007). Government leaders continually face pressures to allocate limited tax revenues to address pressing societal needs, and many have achieved a great degree of success (Wolk, 2007). While social entrepreneurs will never take the place of government, conversations with social entrepreneurs and experts in the field suggest that social entrepreneurship is uniquely positioned to help government officials better address societal needs (Wolk, 2007). Specifically, social entrepreneurs have the capability to help government improve the lives of their constituents in two primary ways: (1) leveraging public and private resources and (2) testing and developing solutions (Wolk, 2007).

Traditionally, government responds in such cases by deploying public funds to address the unmet needs. Social entrepreneurship presents another option for addressing market failures-which can be considered the sources of the opportunities that social entrepreneurs act on (Wolk, 2007). Due to the common objective of addressing market failures in the economy, there is strong evidence to suggest that a hybridized model of governmental and private sector partnership would be ideal of create the incentives required for the institutional support of social 


\section{International Journal of Social Science and Economic Research}

ISSN: 2455-8834

Volume:05, Issue:09 "September 2020"

entrepreneurship models, simultaneously fostering a competitive market in the sector for further innovation.

\section{Discussion}

There exist several government schemes for social innovation and entrepreneurship incentives, specifically to promote participation of women, urban poor, rural communities, and other oppressed identities. The government of India under Prime Minister Narendra Modi launched the Digital India program worth INR 1,13,000 crores (or approximately USD 18 billion) with an aim of transforming India into a digitally empowered society and a knowledge economy by 2019 (Potdar, 2015). Some of the focus areas included providing broadband internet connectivity to over 200,000 villages, making mobile connections and bank accounts available for digital and financial inclusion to 42,300 villages, and universal digital literacy (Potdar, 2015). These movements will become game changing leverage for social entrepreneurs. The National Rural Livelihoods Mission (NRLM), a program under the Ministry of Rural Development (MoRD), which has organized about 56 million women into SHGs, thereby leveraging over $\$ 30$ billion in loans in the last five years (Kutty and Gupta, 2019). NRLM's focus on social and financial inclusion has provided an impetus to women entrepreneurs to invest in their businesses and contribute toward a financially stable future (Kutty and Gupta, 2019).

However, more money could also lead to more problems. For example, as per the new Corporate Social Responsibility guidelines in Section 135 of Companies Act 2013, organizations have to spend at least $2 \%$ of their average net profit of last 3 years on CSR activities (Potdar, 2015). Currently these guidelines prohibit investment in for-profit business models. However, this will still result in availability of an estimated USD 2.5-3.3 billion of CSR funds every year for Indian social ventures (Potdar, 2015). However, data on CSR displays a lack of accountability on the part of both companies and the government, as companies very often display tokenistic donations without making real impact (British Council, 2016). Further, the CSR regime in India allows companies to contribute to relief funds and the government, which removes the need for developing any concrete or detailed plans to assist poorer communities with social entrepreneurship (British Council, 2016).

Governmental regulations on financial or investment related issues may also hamper the progress of social entrepreneurship initiatives. In a survey conducted by the British Council, $14 \%$ of the social enterprises also reported that a major hindrance to securing finance is regulatory constraints when securing capital from international sources (British Council, 2016). Further, regulation poses a problem in terms of the foundation of the enterprise itself. In India, Indian social enterprises must currently incorporate as one of the following: a nonprofit, which cannot legally maintain substantial surpluses from year to year; a private company; or a hybrid structure 


\section{International Journal of Social Science and Economic Research}

ISSN: $2455-8834$

Volume:05, Issue:09 "September 2020"

with separate nonprofit and for-profit entities (Salovaara and Wade, 2018). These choices have material consequences, since some forms of support (such as government contracts under social programs) are largely reserved for nonprofits, while others (such as impact investment funding) are more accessible to social enterprises with a stronger business orientation (Salovaara and Wade, 2018).

Therefore, although collaboration thus far between social entrepreneurs and government has occurred in isolated incidents, working together more strategically represents a yet-to-beharnessed opportunity for government leaders working to resolve social problems (Wolk, 2007). By adapting some of the same levers that have successfully encouraged entrepreneurialism across the world, government leaders have a similar opportunity to support social entrepreneurship - and thereby generate transformative, financially sustainable solutions to social problems facing everyone (Wolk, 2007).

\section{Conclusion}

Success stories in the field of social entrepreneurship do show that profit and social good can occur in parallel. Social enterprises are likelier than others to be led by women and members of minority ethnic groups, who are disproportionately the greatest victims of regulation, especially in the labor market (through minimum wage laws, occupational licensing, and compulsory unionism, for example) (McAffrey, 2015). Social entrepreneurs offer numerous stakeholders a chance to escape the effects of these policies, which are deceptively marketed as compassionate innovations rather than the political entrepreneurship they really are (McAffrey, 2015). A prominent example is the wPOWER India project, which empowers women and women's groups to supply solar technologies to their local communities (Salovaara and Wade, 2018). While women had previously faced domestic violence and demands for dowry, the enterprise has assisted them in becoming entrepreneurs, taking them outside the home to lead demonstrations of solar technologies at markets, schools, and village meetings (Salovaara and Wade, 2018). It is now a successful enterprise, running several profitable businesses selling solar products in rural communities.

It is clear that with the right interventions, a hybrid of government intervention and pure business entrepreneurship, social ventures can address problems that are too narrow in scope to spark legislative activism or to attract private capital (Osberg and Martin, 2015). It is becoming increasingly important for the government to promote awareness of social entrepreneurship and enterprise (British Council, 2016; Osberg and Martin, 2015). More schools, universities, and research organisations need to encourage an entrepreneurial mindset among young people, particularly one geared towards tackling social challenges in communities and generating more jobs (British Council, 2016). 


\section{International Journal of Social Science and Economic Research}

ISSN: $2455-8834$

Volume:05, Issue:09 "September 2020"

There is also potential for collaboration between the government and the private sector investors. Parallel to governmental intervention, the private investment ecosystem has significantly improved over the last decade (Potdar, 2015). Impact investors, social business incubators, and donor agencies are emerging as key players in this space (Potdar, 2015). According to a study conducted by German Society for International Cooperation in 2012, $70 \%$ of impact investors and $56 \%$ of incubators were within the first 5 years of their operations in India (Potdar, 2015). In addition, the government must ensure that CSR spending is routed to appropriate social entrepreneurship initiatives. Provisions should also be made to divert CSR funds into social enterprises irrespective of their legal structure (presently, in India, only NGOs are eligible for CSR funds) (British Council, 2016).

For more vulnerable communities such as women, governments and organizations in the sector must cease only to posit scalability as desirable, and even essential, for a social enterprise to maximize its impact (Salovaara and Wade, 2018). Changing the paradigm from "scaling" a single venture to creating networks of support and knowledge-sharing among smaller ventures might more effectively serve diverse communities' needs through more localized frameworks (Salovaara and Wade, 2018). Governments must create an enabling environment rather than impose onerous regulations. Government often plays a critical role as a resource and partner for producing knowledge that helps identify the problems, document the solutions, and compare various interventions against standards for success (Wolk, 2007; Shockley and Frank, 2011). Government specifically provides research data, establishes critical standards, and produces or funds evaluations that provide critical information for those working toward solving social problems (Wolk, 2007; Shockley and Frank, 2011). With an improvement of these knowledge networks rather than an increase in bureaucracy, the ease of doing business for social enterprises will increase dramatically.

\section{References}

British Council, (2016), 'The State of Social Enterprise in India', https://www.britishcouncil.org/sites/default/files/bc-report-ch4-india-digital_0.pdf

Khanna, A, (29 October 2015), 'Women social entrepreneurs are driving transformation', Livemint, https://www.livemint.com/Opinion/13vonj0SaE4XrJdxyDgn1J/Women-socialentrepreneurs-are-driving-transformation.html

Kutty, B and Gupta, A, (21 February 2019), 'The rise of India's rural women entrepreneurs', World Bank Blogs, https://blogs.worldbank.org/endpovertyinsouthasia/rise-india-s-rural-womenentrepreneurs 
International Journal of Social Science and Economic Research

ISSN: 2455-8834

Volume:05, Issue:09 "September 2020"

Mante, G (2019), 'Social Entrepreneurship in India - Changing the Life of the Poor', Reset, https://en.reset.org/knowledge/social-entrepreneurship-india-\%E2\%80\%93-changing-life-poor

McCaffrey, M, (8 September 2015), 'Social Enterprises Are Fixing What Government Destroys', Foundation for Economic Education, https://fee.org/articles/social-enterprises-are-fixing-whatgovernment-destroys/

Osberg, S and Martin, R, (2015), 'Two Keys to Sustainable Social Enterprise', Harvard Business Review, https://hbr.org/2015/05/two-keys-to-sustainable-social-enterprise

Potdar, R, (2015), 'The Future is Bright for Indian Social Enterprise - Here's Why', Startup

Grind, https://www.startupgrind.com/blog/3-reasons-why-sun-will-shine-on-socialentrepreneurs-in-india/

Salovaara, I and Wade, J, (14 February 2018), 'Women, Prosperity and Social Change in India', Stanford Social Innovation Review, https://ssir.org/articles/entry/women_prosperity_and_social_change_in_india

Salovaara, I and Wade, J, (14 March 2018), 'How to Support Women Social Entrepreneurs in India', Stanford Social Innovation Review, https://ssir.org/articles/entry/how_to_support_women_social_entrepreneurs_in_india\#

Shockley, G and Frank, P, (2011), 'The functions of government in social entrepreneurship: theory and preliminary evidence', Regional Science Association, https://rsaiconnect.onlinelibrary.wiley.com/doi/full/10.1111/j.1757-7802.2011.01036.x

Wolk, A, (2007), 'Social Entrepreneurship and Government', From The Small Business Economy: A Report to the President, 2007, by The Small Business Administration, Office of Advocacy, https://staging.community-wealth.org/sites/clone.communitywealth.org/files/downloads/report-wolk.pdf 